\title{
Aesthetic processes in science education: art based science education*
}

\section{Oğuz ÖZDEMíR ${ }^{* *}$}

\begin{abstract}
Educational processes carried out for information transfer highly hinder the fulfillment of the goals expected to be achieved through learning experiences. In the present study, the place and importance of the usually neglected "imaginary" learning are investigated. Unlike "conceptual" learning dominating the educational processes particularly in the field of science education, this imaginary learning is underutilized. In the present study, in light of the literature review, the potential of artistic and literary communication based on imaginary language to have impact on learning experiences is explained, and based on this, suggestions are made to capitalize on artistic and literary genre for science education.
\end{abstract}

Keywords: Science education, conceptual thinking, imaginary thinking, art, literary genre, literary communication, aesthetic perception.

\footnotetext{
* This study was conducted based on oral presentation "The Place and Important of Literary Genre on Learning Experience", which was made at "Prof. Dr. Cahit KAVCAR Türkish Teaching Workshop ( 13-15 Mai 2010, Ankara).

** Assist. Prof. Dr., Muğla University, Education Faculty, Department of Science Education, Muğla, Turkey. E-mail:oozdemir@mu.edu.tr
} 


\section{SUMMARY}

Purpose and Significance: The study aims to shed light on the educational potential of the art on enhancing the efficiency of science education. The science education carried out with a great emphasize on cognitive activities is inadequate in making use of the imagination capacities of students, hence, restricts the effectiveness of their learning experiences to a great extent. On the other hand, the conventional science education making it possible for people to understand phenomena and events concerning the external world can be argued to be inadequate helping learners to understand the unity, complexity and variability among these phenomena and events. Through its arousing effect on senses, perceptions and thinking skills of individuals, the art can be influential in students' comprehending the external world by going behind the restrictive and reducing framework of conceptual and analytic thinking. This shows that an education program enriched with the works of art can be effective in instilling creative dimension to science education.

Method: The present study utilized review method to evaluate the ideas and opinions presented in the literature concerning scientific illustration and art education.

Discussion and Conclusions: The practices of science and art education have long been carried out in isolation from each other in such a way as to fortify the "insulation" between the world of "cognition" and "imagination". This leads, on the one side, to natural sciences' impoverishing the human mind and on the other, art education's being increasingly introverted. It seems highly possible to improve the efficiency of science education by increasing the interdisciplinary interaction between science and art. However, there is paucity of research in our country to shed light on how to make use of the works of arts in educational experiences, in particular, in science education.

The present study is limited to the aim of explaining the role and place of works of art and literary genre in science education within the framework of the concepts of scientific illustration and art education. It is clear that there is a need for applied studies and pioneering institutional research that will help science education to be enriched and obtain a creative dimension through the works of art. 


\title{
Bilim Eğitiminde Estetik Süreçler: Sanat Destekli Bilim Eğitimi*
}

\author{
Oğuz ÖZDEMiR ${ }^{* *}$
}

\begin{abstract}
ÖZ. Bilgi aktarmaya dayalı olarak yürütülen eğitim süreçleri, öğrenme yaşantılarının beklenen sonucu vermesini önemli ölçüde sınırlamaktadır. Bu çalışmada, başta bilim eğitimi olmak üzere eğitim süreçlerinde ağırlıklı şekilde yer tutan "kavramsal" öğrenme durumlarından farklı olarak, yeterince değerlendirilemeyen "imgesel" öğrenmenin öğrenme yaşantılarındaki yeri ve önemi irdelenmektedir. Çalışmada, alan yazın taraması ışı ̆̆ında, imgesel dile dayanan sanatsal ve yazınsal iletişimin öğrenme yaşantıları üzerinde yaratabileceği etki gücüne açıklık getirilmekte, buradan hareketle sanatsal ve yazınsal ürünlerin bilim (Fen) eğitiminde değerlendirilmesine dönük öneriler getirilmektedir.
\end{abstract}

Anahtar Sözcükler: Bilim (Fen) eğitimi, kavramsal düşünme, imgesel düşünme, sanat, yazınsal ürün, yazınsal iletişim, estetik algı.

\footnotetext{
* Bu çalışma, 13-15 Mayıs 2010 tarihinde gerçekleştirilen "Prof. Dr. Cahit KAVCAR Türkçe Öğretimi” çalıştayında sözlü olarak sunulan "Öğrenme Yaşantılarında Yazınsal Ürünlerin Yeri ve Önemi” başlıklı bildiriye dayalı olarak hazırlanmıştır.

${ }^{* * *}$ Yrd. Doç.Dr., Muğla Üniversitesi Eğitim Fakültesi Fen Bilgisi Öğretmenliği Bölümü, Muğla, Türkiye. E-posta: oozdemir@mu.edu.tr
} 


\section{GİRİŞ}

Bilgilendirmeye dayalı olarak yürütülen eğitim süreçleri, bireylerin öğrendiklerini içselleştirmelerinde büyük ölçüde yetersiz kalmaktadır. Bunda, bilim eğitiminin ağırlıklı olarak bilgilendirme ve becerileri kazandırma sınırlılığında yürütülmesinin, dolayısıyla öğrencilerin bilişsel ve duyuşsal dünyaları arasında anlamlı ilişkiler kurmalarını sağlayabilecek alternatif öğrenme yaşantılarına yeterince yer verilememesinin etkili olduğu söylenebilir. Bu durum, "bilimsel açıklamaya" odaklı yürütülen bilim eğitiminin, bireylerin yeni bilgileri "tanıma" ve "değerleştirme" yetilerini olanaklı kılacak alternatif eğitim durumlarıyla desteklenmesini gerekli kılmaktadır.

Sanat'1n, öteden beri insanoğlunun birbirinden "yalıtılmış" olan "akıl" ve "imge" dünyasının tekrar birbirine bağlanarak zengin şekilde etkileşime girebilmesinde, dolayısıyla algılama ve duyumsama kanallarının açılmasında etkili olabileceği düşünülmektedir. Sanat ürünlerinin, insanın duyum, alg1 ve anlama yetilerini açığa çıkarma, dolayısıyla öğrenme yaşantılarını zenginleştirme açısından taşıdı ̆̆ı "eşsiz" potansiyelinin yeterince bilindiği ve değerlendirildiğini söylemek ise pek mümkün değildir.

$\mathrm{Bu}$ çalışmanın çıkış noktasını, sanat ürünlerinin bireylerin duyum, algı ve anlama yetilerini harekete geçirerek bilim eğitiminde öğrenme yaşantılarının etkililiğini artırabileceği savı oluşturmaktadır. Buradan hareketle, sanatın öğrenme yaşantılarını nasıl zenginleştirebileceğine yanıt aranmakta ve bu yönde öneriler getirilmektedir.

\section{İki Tür Düşünme Etkinliği: İmgesel ve Kavramsal Düşünme}

İnsan, gerçekliği bir yandan duyularının aracılığıyla ulaştığı duyumlarla algılarken, diğer yandan ise ussal ağırlıklı zihinsel etkinliklere dayalı mantıksal çözümleme ve ilişkilendirmeler yoluyla kavramaya ve anlamlandırmaya çalışmaktadır (Erzen, 2006). İlkinde, insan duyumlara dayalı olarak kurulan imgelerin çok yönlü, sonsuz ve değişken dünyasına açılırken; ikincisinde ise mantıksal faaliyetlerin sınıflayıcı, ayrıştırıcı ve sınırlayıcı gerçekliği içinde olup bitenleri algılama ve anlamaya odaklanmaktadır (San, 2003). İnsanın, gerçekliği imgeler aracılığıyla dolaysız algılaması, "sentetik", buna karşın kavramlar aracılığıyla tanıması ise "analitik" düşünsel etkinlik olarak kabul edilmektedir (Erzen, 2006). Söylemsel (diskursiv) etkinliklerin temelini oluşturan analitik düşünme, Akarsu (Akt. San, 2003: 32)'ya göre “bir tasarımdan ötekine geçerek, bir önermeden ötekine mantıksal yolla ilerleyen, parçalardan, bütünlüğg̈ olan bir düşünce kuran düşünme yolu" olarak betimlenmektedir. Bu bağlamda, analitik algının gündelik yaşamda temel insan gereksinimlerinin pratik 
şekilde karşılanmasına hizmet ederken; sentetik algının bunun ötesine geçerek insanı sonsuz ve zengin keşif olanakları sunan estetik yaşantıların içine soktuğu belirtilmektedir (Erzen, 2006).

San (1979: 184-185) insanın söz konusu iki farklı yönlü düşünme etkinliği arasındaki farklılığı, "imgesel düşünme" ve "kavramsal düşünme" edimlerini kıyaslayarak şöyle ortaya koymaktadır:

"Gereçleri salt kavramlardan oluşan bu ussal düşünmeye karşın, gereçleri zihinsel resimler yani imgeler olan "imgesel düşünme", bilgi alma işlemini de imgesel yoldan yapmaktadır. Bir anlamda bilgi alma gereci de gene imgelerdir; yöntemi kıyaslamadır. Çizgisel olmayıp çok yönlü olan imgesel düşünme, aynı zamanda çok anlamlı, çok boyutludur; sonuçları doğru ya da yanlış değil, berrak, açık-seçik ya da bulanık, karmaşıktır. Ussal düşünme nedenselliğe, neden-sonuç ilişkisine yönelirken, imgesel düşünme anlama ve erekliliğe (finalite) yönelir."

Özellikle, sözlü kültürlerde gerçekliğin şiirsel yöntemler, destanlar ve söylenceler yoluyla dolaysız şekilde ve bütünlügüüne algılandığı; daha sonra bunun yerini bilgi aktarımına dönük çizgisel kavrayışın aldığ vurgulanmaktadır. Buradan hareketle, "estetik" şsekilde kavranılan dünya tanımının yerine, zihinde tasarlanan "kavramsal" dünya algısının geçtiğine dikkat çekilmektedir (San, 2003; Erzen, 2006). Bunda, kökleri antik Yunan'a uzanan insan zihninin işleyişinde duyuları büyük ölçüde dışarıda tutan akılcılığın etkili olduğu düşünülmektedir. Arnheim (2009)'a göre, akıl yürütme, uzun bir süre karmaşı ve belirsiz olan dış dünyaya ilişkin duyusal iletileri netleştirmenin başlıca yolu olarak kabul edilmiş, dolayısıyla "akıl" ve "duyu" nun birbirinden iyice yalıtılmış olduğu anlayışı hakim olmuştur. Oysa Arnheim (2009), başta görme duyusu olmak üzere duyuların dış dünyanın nesneleri ve olayları hakkında bitip tükenmez zenginlikte bilgi sunduğunu belirterek duyusal etkinliklerin akıl yürütmeyi zenginleştirici yönünü özellikle vurgulamaktadır. Buradan hareketle Arnheim (2009), kavramların "algısal imgeler" olduğu ve düşünce işlemlerinin de bu imgeler sayesinde gerçekleştiği çıkarsamasını yapmaktadır (Arnheim, 2009).

Ağırlıklı olarak imgeler ve semboller aracıllğıyla gerçekleşen çok yönlü ve boyutlu estetik algılama ve düşünme uğraşı, Langer (Akt. San, 2003)'e göre "görüsel (presentative)", Daucher ve Seitz (Akt. San, 2003)'e göre "imgesel (imaginary)", Ponty (2005)' e göre "estetik” düşünme şeklinde nitelendirilmektedir. Sözü edilen düşünme etkinlerine dayanan sanatsal iletişimin, algılamanın kanallarını açarak "estetik uyanış" yarattığı, bu şekilde duyumsal, duyuşsal ve zihinsel süreçleri tetikleyerek bireylerin olup bitenleri daha çok yönlü ve derinlemesine tanımasında etkili olduğu üzerinde durulmaktadır (Ponty, 2005; Sahasrabudhe, 2006). 


\section{Bilim (Fen) ve Sanat}

Sanatın bilim (fen) eğitiminde oynayabileceği role açıklık getirebilmek için, her şeyden önce "sanat" ve "bilim"den ne kastedildiğinin netleştirilmesinde yarar vardır. Göstergebilimin önemli kuramcılarından Arnheim (2009), sanat ve bilim etkinliğini "gerçekliği" anlama ve açıklama çabasının ortak aracı olarak kabul etmektedir. Bu bağlamda Arnheim (2009), her ikisini de duyusal dünyayla algılanan şeylerin imzası (signatura rerum) olarak nitelendirmektedir. Ancak bu, ağırlıklı olarak sanatta " imgelerlerle", bilimde ise "kavramlarla" yerine getirilmektedir.

Arnheim (2009: 261-262), bir gözlemcinin resimle başbaşa kalması sırasında gerçekleşenleri temel alarak, insanın sezgisel ve zihinsel bilme yetisine şöyle açıklık getirmektedir:

"Sezgisel bilme yetisi, serbestçe etkileşen kuvvetlerin algısal alanında gerçekleşir. Bir resme yönelen gözlemci çerçevenin kuşattığı bölgeyi tarayarak, resmin çeşitli bileşenlerini, biçimleri, renkleri ve bunlar arasındaki ilişkileri algılar. Bu bileşenler algısal etkilerini birbirlerine öyle bir aktarır ki, gözlemci, imgenin tamamını bileşenler arası etkileşimin bir sonucu olarak kavrar".

Arnheim (2009: 262), aynı örnekten yola çıarak sanat ürünlerinin algılanmasında zihinsel bilme yetisinin sinırlılı̆̆ını şu şekilde dile getirmektedir:

"Zihinsel bilme yetisi ise aynı gözlemcinin resim yapıtını oluşturan çeşitli bileşenler ve ilişkileri teşhis etmek istemesiyle kendini gösterir. Böylece, yapıtı zihinsel olarak çözümlemeye yönelen gözlemci, resmi oluşturan bileşenlerin her birinin tikel doğasını kurmak amacıyla, parçaları ve parçalar arasındaki ilişkileri algısal anlamda yalıtarak, dolayısıyla doğrudan deneyimden kazanılan algısal kavramları yavaş yavaş katılaştırarak, tutarlı düşünmeye katkıda bulunan kararlı şekillere ulaşır.

Göstergebilimin önemli kuramcılarından Langer (Akt. San, 2003), sezgisel düşünmenin malzemesi olarak kabul edilen görsel biçimlerin, kavramsal düşünmenin malzemesi olan söylemsel biçimlerden farklı olarak, öğelerini ardı ardına ve sırayla değil, aynı anda ve birden sunarak daha bütünlüğüne kavrayışs sağladıklarına dikkat çekmektedir.

Buradan hareketle, sanatın temel malzemesi olan imgesel düşünmenin bilimin malzemesi olan zihinsel düşünmeye göre daha "sahici" ve "kavrayıc1" olduğu söylenebilir. Nitekim Arheim (2009: 334), sanat ve bilimdeki "kesinlik" ölçütlerini karşılaştırırken şöyle demektedir: "Bilimsel bir tanıtlamada, gösterilen şeyin görünümü deneyin geçerliliği açısından ancak olguların emaresi olması ölçüsünde önemlidir. Bu çerçevede, ders kitabındaki laboratuar çalışması ve şema, bilimsel beyan değil, sadece bu tür 
beyanların salt göstergeleri, başka bir deyişle illustrasyonlarıdır, oysa sanatlarda imge beyandır, kendiliğinden söz ettiği kuvvetleri kapsar ve sergiler".

Buradan hareketle Arnheim (2009), sanatın doğrudan insani deneyim ve tepkilerle varlık kazandığını belirterek, bu şekilde sanatsal ürünlerin bilimin mesajını tamamladığını ileri sürmektedir. $\mathrm{Bu}$ noktada, sanat yoluyla eğitimin önde gelen kuramcılarından Read (Akt. San, 2003:136: )'e ise, sanatın bilimden farklı olarak zengin deneyimsel yaşantılara dayandığını çarpıcı şekilde şöyle ifade etmektedir: "Sanat bir canlandırmadır, bilim bir açıklamadır, her ikisi de gerçeklikle uğraşır, biri onu canlandırır, diğeri ise açılar".

\section{Bilim Eğitiminin Sorunları ve Sınırlııkları}

17.yüzyıldan itibaren pozitif bilimlerde sağlanan buluşlar ve ilerlemeler, bilimi neredeyse evreni anlamanın ve düzenlemenin en geçerli yolu haline getirmiştir. Bilimde devrim niteliğinde atılan bu adımlar, modern hayatın temelini oluşturacak "determinist pozitivist" ilerleme anlayışının yerleşmesini beraberinde getirmiştir (Morin, 2003). Morin (2003)'e göre, modern çağa yön veren "aklın ve tekno-bilimin hegemonyası", aynı zamanda bilim eğitiminin temelini oluşturmuş ve şekillendirmiştir. Böylece, bilim eğitimine, ortaya çıkan insan gereksinimleri doğrultusunda evreni daha fazla yönetebilecek bilgi ve beceride nesillerin yetiştirilmesi beklentisi yüklenmiştir.

Ancak, aklın ve tekniğin yönlendiriciliğinde tek boyutlu şekilde yürütülen bilim eğitiminin, insan hayatında ve doğada yol açtı̆̆ 1 öngörülemeyen tahribatlar, bireylerin çok yönlü ve derinlemesine kavrayış edinmelerinde ve yaşam doyumuna ulaşmalarında yetersiz kaldığını göstermektedir. Günümüzde teknolojik ürünlerin "yapay bir makina"ya dönüşerek insanı yönetecek duruma gelmesi, bilgilendirme ve beceri edindirme sınırlılığında yürütülen bilim eğitiminin doğal sonucu olarak kabul edilebilir (Morin, 2003). Bu durum, geleneksel anlayışa göre yürütülen bilim eğitiminin öğrencilerde, teknolojinin yaratacağı fırsatların yanında, özellikle toplum hayatı ve doğada beklenemeyen olumsuzlukları öngörebilecek kritik düşünme becerisi ve duyuşsal donanım kazandıramadığını göstermektedir. Mevcut bilim eğitiminin, olguları "bağlamı", "bütünlüğüu”, "çok boyutluluğu” ve "karmaşıklığıyla" kavratacak ve bu yönde içgörü kazandıracak nitelikten uzak olması, Morin'in (2003) deyişiyle adeta "bilmenin körlüğ̈̈̈" ne yol açmaktadır. Morin (2003) buradan hareketle, "indirgeyici zihne" dayalı olarak yürütülen bilim eğitiminin insana dair öznenin bilgisini ve bilincini kazandıramadığını, dolayısıyla 
"akılsallığın" hakim olduğu bilim eğitiminin bireylerin algılama ve düşünme yetilerini körelttiğini vurgulamaktadır.

Öğrencilerin yaratıcılıklarının kanallarını açacak öğrenme yaşantılarına yeterince fırsat verilememesi, bilim eğitiminin diğer öncelikli sorunlarından biridir. Eğitim süreçlerinde öğrencilerde "gözlem", "ölçme", "sınıflama", "hipotez kurma", "değişkenleri test etme" ve "sonuç çıkarma" gibi temel bilimsel süreç becerilerinin istenilen düzeyde kazandırılamaması, bilim eğitiminin öğrencilerin yeterince yaratıcılıklarını besleyemediğinin göstergesi olarak kabul edilebilir. İçinde bulunduğumuz bilim eğitimi pratiğinin, duyusal açıklık ve yoğunlaşma sağlayamadı̆̆g için, öğrencilerin özellikle gözlemleme becerilerinin gelişmesinde yetersiz kaldığı yadsınamaz bir gerçektir. Erzen (2006) bu durumu, kısaca "algısal uyuşukluk" olarak nitelendirmektedir.

Bilim eğitiminin içinde bulunduğu betimlenen açmaz, çizgisel algılamaya yönelik olarak yürüyen mevcut bilim eğitimi pratiğinin, imgesel algının çok yönlü ve bütünlügüune keşfettirici ve zenginleştirici yönünden yoksun kalmasıyla açıklanmaktadır (Erzen, 2006). Bu durum, bilim eğitimi süreçlerinin öğrencilerinin duyum ve duyuşsal dünyalarını besleyebilecek araçlarla zenginleştirilmesi gerekli kılmaktadır. Sanat, bu noktada sunduğu estetik deneyimlerle insanoğlunun birbirinden yalıtılmış akıl ve imge dünyasının tekrar birbirine bağlanarak zengin şekilde etkileşime girebilmesinde, dolayısıyla öğrencilerin bilimsel yaratıcılıklarının önünün açılmasında etkili olabilir. Bu çalı̧̧manın çıkış noktasını, sanat ürünlerinin bireylerin algısal farkındalıklarının artmasında ve duyuşsal uyanış yaşamalarında, dolayısıyla yaratıcılık kanallarının açılmasındaki etki gücü oluşturmaktadır.

Ancak, konuya eğitim süreçleri açısından bakıldığında, sanat ve bilim eğitiminin insanın "birbiriyle çatıştığı kabul edilen" "duygu" ve "akıl" yetilerinin işlenmesi üzerine kurulu iki ayrı düzlemde yürüdüğü yönünde yaygın bir anlayışın hakim olduğu söylenebilir. Arnheim (2009) bu durumu, bir yandan fen bilimlerinin mevcut pratiğinin insanın zihnini yoksullaştırması, öte yandan ise sanat eğitiminin kendi içine kapalı şekilde yalıtılmıs olmasına bağlamaktadır. Buradan hareketle Arnheim (2009), bunun çaresinin fen bilimlerinden kaçıp sanatlara sığınmakta değil, bilim eğitiminin geliştirilmesinde aranması gerektiğine dikkat çekmektedir. Tam bu noktada, bilim eğitimi ile diş dünyaya ilişkin olaylar ve nesneler anlaşılır ve belirgin hale getirilirken, bunlar arasındaki çok yönlü ilişkiselliğin, bütünlüğün karmaşıklığın ve değişkenliğin bütünlüğüne nasıl algılatılabileceği sorusu kritik bir önem kazanmaktadır.

Arnheim (2009), bilimci ya da felsefecinin sözcüklerle ya da başka tür simgelerle temsil edilen örgütlenmiş modeller üzerinden bildirişim kurarken, 
insanın bu modelleri nasıl örgütlediği üzerinde uzman olan sanatçının yardımından uzak kalmaması gerektiğini belirtmektedir. Buradan hareketle, mevcut bilim eğitimi pratiğinin zenginleşebilmesinde, şu ana kadar bir birinden bağımsız olarak görülen bilim ve sanat pratiğinin disiplinlerarası şekilde işbirliğine sokulmasının etkili olabileceği anlaşılmaktadır.

\section{Bilim Eğitiminde Sanat}

Bilim ve sanat, öteden beri insanoğlunun "rasyonel" ve "estetik" olmak üzere birbirine zıt olarak görülen evreni anlama biçiminin karşılıkları olarak kabul edilmiştir (Arnheim,2009). Bu durum, Langer (Akt. San, 2003) insanın farklı yönlü ve nitelikteki düşünsel etkinlik alanlarının söylemselgörüsel, kavramsal-imgesel şeklinde birbirinden yalıtılmasına bağlamaktadır.

Yukarıda üzerinde durulan insanın iki yönlü anlama etkinliğinden birincisi ile varolan ve gerçeklik ağırlıklı olarak çizgisel ve mantıksal şekilde kavranabilirken, buna karşın estetik etkinliğinin özünü oluşturan ikincisi sayesinde imgesel düşünmenin zengin olanaklarının işe koşulması ile çok boyutlu ve katmanlı kavrayışın kanalları açılabilmektedir (San, 2003). Bu durum, sanatın insanın düşün ve imgelem potansiyelini harekete geçirebilecek bir gücünün olduğunu göstermektedir.

Sanatın eğitimde uygulanmasına yönelik metodolojik yaklaşımlar, sanatın "araçsal" ve "değer" yönlerini çıkış noktası almalarıyla birbirlerinden ayrılmakta ve dile getirilen anlayışlar "eğitim ağılrlıklı sanat eğitimi " ve "sanat ă̆ırlıkl sanat ĕgitimi " şeklinde iki ayrı ekol içinde yer almaktadırlar(San, 2003).

Bu çalışmanın üzerinde durduğu "sanat yoluyla eğitim" anlayışını öne çıkaran yaklaşımların ayırt edici ortak özelliği, sanatın özgüllü̈̆ünü korumak kaydıyla bazı eğitsel işlevlerinin "didaktik" amaçlı değerlendirilmesinden yana olmalarıdır (San, 2003).

\section{Yazınsal İletişim ve Bilim Eğitimi}

Bilim eğitiminde sanatın değerlendirilmesinin diğer bir yolunun ise, öğrencilerin bilimsel kavramları öğrenirken yazınsal ürünlerle iletişim kurmalarından geçtiği söylenebilir. Güzel sanat türü olarak yazınsal ürünlerle kurulan iletişimin, duyuları harekete geçirici ve algıları zenginleştirici potansiyelinin olması öğrenme-öğretme süreçlerinin etkililiğini artırabileceğini akla getirmektedir. Bu çalışmada, dilin öğrenme durumlarında yaygın şekilde kullanılan söylemsel işlevinden farklı olarak yazınsal ürünlerde beliren imgeleri harekete geçirici özelliği üzerinde durulmaktadır. 
Zimmermann (2001) yazınsal ürünlerin bireylerin biliş ve duyuş dünyaları üzerindeki etkisini, dilin "simgesel (symbolic)" ve "göndergesel (referantial)" anlatım şeklini karşılaştırarak açıklamaktadır. Ona göre, simgesel anlatım bireyin yaşantılarına dayalı duygu dilini, göndergesel anlatım ise bireysel deneyimlerinden bağımsız entelektüel dilini oluşturur. $\mathrm{Bu}$ anlamda, simgesel dile dayalı yazınsal ürünlerin, yarattığı sezgi gücü ile bireyin imgelem ve kavrayış dünyası arasında köprü kurarak etkisini gösterdiği ileri sürülmektedir.

Richards (Moran, 2006: 237-238), edebiyatın işlevini Zimmermann (2001)'e benzer şekilde, "dilin işlevi” üzerine ileri sürdüğü görüşlerle temellendirmektedir. Richards'a göre dilin göndergesel ve "duygusal (affective)" olmak üzere iki tür işlevi vardır. Dil, göndergesel, kısaca bilgilendirme işlevini bilim yazılarında ve gazete makalelerinde yerine getirir. Duygusal işlevini ise yazınsal yapıtlarda gerçekleştirir.

Buna göre, yazınsal ürünlerde kurulan dilin yazınsal olmayan metinlerdeki dilden farklı olarak, oluşturdukları imgeler yolu ile kavrayışın ve duyuşun sınırlarını genişletebileceği ortaya çıkmaktadır. Bu bakımdan, yazınsal ürünlerle kurulan iletişimin sağladığı "estetik yaşantı" süreçlerinin diğer anlatılara göre alımlayıcının duygu dünyasında farklı bir etki yaratabileceği söylenebilir.

Edebiyatın insanın duyuşsal gelişim eğitimi açısından değerlendirilmesi düşüncesi, büyük ölçüde 18. ve 19 y.y. romantik edebi akımlarından beslenmektedir. $\mathrm{Bu}$ anlamda edebiyatın eğitsel gücünü Carr (2005), duyguların eğitilmesi ve saflaştırılıp inceltilmesinde anahtar bir rol oynamasına bağlamaktadır. Ona göre, şiirin gücü sadece insanın bilişsel gelişimine ya da duygularını değerlendirmesine yardımcı olmasından değil, aynı zamanda yaşantısal duygulanımın beslenmesinden gelmektedir.

Kavcar ise (1994:5), yazınsal ürünlerin eğitsel etkisini, "Eğitim bakımından edebiyatın değeri, insana çok çeşitli duyma, düşünme ve hareket etme örnekleri vermesinden gelmektedir. Bir insan ancak böyle geniş bir ortam içinde kendisiyle uygun olan yolu seçme özgürlüğü kazanır" şeklinde vurgulamaktadır. Uygur (1984:160)'a göre edebiyat, duygu insanın tüm duygu kanallarını ve olanaklarını açmasıyla, diğer bir deyişle duygu eğitimi sağlamasıyla etkisini göstermektedir.

Göktürk (1989), yazınsal ürünlerin kurduğu yazınsal iletişim sayesinde bireyleri gerçek-gerçekdışı, deneysel-kurmaca, somut ve soyut arasında yalpalatarak, dolayısıyla düş gücünü harekete geçirerek yaratıcılıklarını tetiklediğini belirtmektedir. Edebiyatın bireyde bilgilendirici ve yönlendirici göndergesel metinlerden farklı olarak yarattığ 1 etkiyi Göktürk (1989: 1)'ün aşağıda alıntılanan görüşleri bütün açıklığıyla ortaya koymaktadır: 
“......sanatın dile getirmeyi amaçladığı gerçek, hiç de bilimsel doğrunun ölçütleriyle değerlendirilemez. Bilim, deneylerle kesin hesaplarla kanıtlayarak sunar yasalarını. Bir roman ya da şiir ise, bir takım olaylarla durumları, çoğunlukla sezdirme yoluyla, duyarlılı̆̆ımıza seslenerek verir. Sözgelişi, bilim adamı çok uzak bir gezegene ya da okyanusun dibine yapılacak bir gezinin bütün hazırlığını en ince elektronik hesaplarla gerçekleştirirken, o gezinin büyüsünü, kıvancını, coşkusunu, ürpertisini dile getirmek, yazarın yaratıcılık alanına girer, öte yandan insanlarla bütün öbür canlıları bir arada yeryüzünden siliverecek "temiz bomba", bilim adamının büyük buluşlarından biri diye görülebiliyorsa, bu sözde büyük buluşun gelecekteki sonuçlarından duyulan korku ile yılgınlığı dile getirmek de yaratıcı yazarın başarısı olacaktır".

Yukarıdaki değerlendirmelerden hareketle, sanatın ve özel bir sanat türü olan yazınsal ürünlerin bilim eğitimini zenginleştirici etkisi, üstlenebileceği işlevlere bağlı olarak açıklanabilir. Bu çerçevede, Götze (Akt. San, 2003), sanatın bireylerin "görü (ya da sezgi)" ve "düşünme" ile "tanıma" ve "bilme" etkinliklerini birbiriyle canlı bir ilişkiye sokarak daha zengin ve derinlemesine kavrayışa hizmet edebileceğini belirtmektedir. Sahasrabudhe (2006)'e göre ise sanat, insanın "biliş" ve "duyuş" alanını besleyerek eğitim süreçlerinde iki yönlü şekilde etkili olabilmektedir. Bu anlamda sanat, bir yandan insanın zihinsel yetilerinin sınırlarını genişletirken, diğer yandan ise bireyin çevresini duyuşsal deneyimleriyle etkili şekilde "tanımasının" itici gücünü oluşturmaktadır.

Öte yandan sanatın, sunduğu zengin duyusal uyarıcılar sayesinde aynı anda birbirinden farklı duyumların kanallarını açabilecek potansiyel taşıması, etkili bir duyu ve alg1 eğitimi aracı olabileceğini düşündürtmektedir. Bu bağlamda, İpşiroğlu (1996) sanat yoluyla eğitimi, duyu ve görme eğitimi olarak nitelemekte ve sanatın "görsel düşünmeyi" sağlayacağını belirtmektedir. Langer (Akt. San, 2003) sanatın, çocuğu doğanın ve yaşamın içine sokarak ve çocuğun bilincini doğa biçimlerine ve doğadaki renklere, seslere ve canlıların devinimlerine ilişkin anı imgeleriyle doldurarak zengin bir duyum eğitimi sağlayabileceğini belirtmektedir. Ponty (2005) ise sanatın renk, koku, ses, v.b. gibi farklı duyumları kendi aralarında etkileşime sokarak duyumsal algılamayı zenginleştirebileceğini öne sürmektedir. Bunun yanında, sanat, duyguların insandan insana geçmesinin sağlayarak, bireylerin duyuşsal dünyalarının vazgeçilmez bir besin kaynağ 1 olabilir. Bu bağlamda Carr (2005), sanatın duyguların eğitilmesinde ve inceltilmesinde anahtar bir rol oynadığını öne sürmektedir. Uygur (1984)'a göre edebiyat, insanın tüm duygu kanallarını ve olanaklarını açmasıyla, diğer bir deyişle duygu eğitimi sağlamasıyla etkisini göstermektedir. 
Bilgilendirme ve beceri kazandırma ağırlıklı yürütülen bilim eğitimi süreçlerinin, insanın "sorma-bilme" dürtüsünün kaynakları olan "karmaşıklık", "uygunsuzluk", "yenilik", "şaşırtıcılık" ve "belirsizlik" durumlarıyla karşılaşmasına yeterince fırsat vermemesi nedeniyle öğrencilerin yaratıcılıklarına ket vurduğu belirtilmektedir (Öztürk, 2004). Bu bağlamda, sanatın, yaratıcılığı besleyen en etkili insan etkinliği olduğu dikkate alındığında, eğitim süreçlerinde öğrencilerin yaratıcılıklarının kanallarını açılmasında kilit şekilde rol oynayabileceği ortaya çıkmaktadır. Buna göre, sanatın bilim eğitiminin yaratıcı nitelik kazanmasında, dolayısıyla bilme ve anlamanın olanaklarının genişlemesinde eşsiz şekilde fırsatlar sunabileceği anlaşılmaktadır.

\section{TARTIŞMA VE SONUÇ}

Kökeni Antik Yunan'a kadar uzanan duyuları dışlayan düşünme anlayışı, 18 yy'da gelişen akılcılık akımı ile iyice pekişmiş ve günümüze kadar özellikle bilim eğitimi süreçlerine ağırlıklı şekilde yön vermiştir. Bunda, çizgisel ilerleyen kavramsal düşünmenin dış dünyayı belirgin, anlaş1lır ve düzenlenebilir duruma getirebilmesine olanak vermesinin önemli bir payının olduğu söylenebilir. Ancak, bu durum aynı zamanda dış dünyanın imgesel yolla çok yönlü ve bütünlüğüne kavranabilmesinin önünde büyük ölçüde engel oluşturmaktadır.

Arnheim (2009), temel eğitimden yüksek öğrenime kadar günümüz eğitim sistemlerinin duyuların eğitsel konumunu dışlayan, sözcük ve sayıların öğretilmesine indirgenmiş şekilde hakim disiplinlerin baskısı altında yürüdügüune dikkat çekmekte ve bu durumu "eğitsel karartma" olarak nitelemektedir. $\mathrm{Bu}$ süreçte, güzel sanatların, akıl yürütmenin ve zihinsel süreçlerin gelişimine katkısı göz ardı edilmiş ve sanatlar giderek hoş beceriler kazandırma, eğlence ve kafa boşaltma aracı olarak görülmüştür.

Oysa, eğitimi etkin kılmaya yönelik arayışlarda, insanın en eski anlama yetisi olarak bilinen estetik algılama potansiyelinin değerlendirilebilmesi yeniden önem kazanmış durumdadır. Öğrencilerin dünyayı kavramsal ve analitik düşünmenin sınırlayıcı ve indirgeyici çerçevesinin ötesine geçerek, imgesel düşünmenin olanaklarıla bütünlüğüne ve derinliğine keşfedebilmeleri, önemli ölçüde sanat ve yazınsal ürünlerin olanaklarıyla zenginleşmiş estetik öğrenme yaşantılarından geçmelerine bağlıdır.

Kuşkusuz, burada kastedilen, sanatın ve yazınsal ürünlerin salt “yararcılık" ölçüsüne indirgenmiş bir rolü ve bu rolün araştırılması değildir. Yüzyıllardır tartışması süren sanatın işlevlerini, yararcı bir çerçeveye indirgemek doğru olmamakla birlikte; bilimsel olguların ve kavramların keşfedilmesi ve bütünlüğüne öğrenilmesinde sanatın öğrencilerin duyum ve 
algılarını harekete geçirici gücünün "didaktizme" kaçmadan değerlendirilmesi etki yaratabilir. Nitekim bireylerin alg1 ve kavrama yetilerinin büyük ölçüde düşlem dünyalarından beslenmesi (Morin, 2003), eğitim süreçlerinde duyuşsal uyanış sağlayabilecek sanat ürünlerinin etkili şekilde değerlendirilmesinin önemini açıkça ortaya koymaktadır. Bu, bilim eğitiminin içine düştüğü çıkmazın aşılması açısından alternatif bir yaklaşım olabilir. Bunun için, öğrenme ve öğretme anlayışında zihinsel işlevlerin duygusal süreçlerle inceltilmesine yönelik köklü bir bakış açısı değişikliği gerekmektedir.

Sonuç olarak, günümüz eğitim sisteminin içinde bulunduğu bu durum, sanat pratiğinden kopuk bilim eğitiminin bireyleri imgesel düşünmenin zenginleştirici yönünden yoksun bırakmaktadır. Öğrenme yaşantılarında bilim pratiği ile sanat pratiğinin işbirliği içine sokulmasının yaratabileceği etkiye ilişkin olarak şu çıkarımlara varılabilir:

1. Sanat ve yazınsal ürünler öğrencilerin duyularını harekete geçirerek duyum ve imgelem yetilerini destekler. Bu durum, eğitim sisteminin öğrenciler üzerinde yarattığı "duyumsama uyuşukluğu"'nun aşılması ve yaratıcılıklarının geliştirilmesini kolaylaştırabilir.

2. Sanat ve yazınsal ürünlerle kurulan iletişim ve geçirilen estetik yaşantılar, öğrencilerin duyma ve görme biçimlerini zenginleştirerek duygusal anlamda eğitir. Böylece, öğrencilerin öğrendiklerini bütünlüğüne tanımalarında ve içgörü kazanmalarında etkili olabilir.

3. Kuşkusuz sanat ve yazınsal ürünler yukarıda ifade edilen etki gücü sayesinde, öğrenme-öğretme süreçlerinin ilgi çekici ve zevkli hale gelmesinde etkili olabilir.

Ancak, sanatsal ve yazınsal ürünler içindeki iletiler sayesinde öğrencilerin bilimsel kavramları ve olguları sanatın özgünlüğünü bozmadan ve " didaktizme" kaçmadan çok yönlü ve derinlemesine tanımalarının nasıl sağlanacağı en kritik tartışma konusudur. Bu noktada, Arnheim (2009)'in bilim pratiği ile sanat pratiğinin etkileşime sokulabilmesine yönelik işbirliği önerisi öne çıkmakla birlikte, bunun nasıl yerine getirileceğine yönelik kuramsal çalışmaların ve pratiklerin yetersiz olması önemli bir güçlük yaratmaktadır.

Estetik süreçlerin bilim eğitiminde değerlendirilebilmesine yönelik sınırlı sayıdaki araştırma ve uygulamalar arasında Andrew ve ark. (2010)'nın gerçekleştirmiş oldukları çalışma dikkat çekmektedir. Anılan çalışma, biyoloji, sanat, bilgisayar, tıp alanında farklı uzmanlarından oluşan araştırma ekibi tarafından bilim ve görsel sanatların bütünleştirilmesinin öğrencilerin kavrayışları üzerindeki etkisini ortaya koymak üzere yürütülmüştür. Araştırma sonucunda, sanat öğrencilerinin artistik dijital görselleştirme becerileriyle zebranın omurgasını bütünlüğüne tasarlayabildikleri; öte 
yandan bilim öğrencilerinin ise zebra omurgasına ilişkin bilimsel imajlarının daha belirgin hale geldiği saptanmıştır. Konuyla ilgili Türkiye'de yapılan sınırlı ölçüdeki çalışmalar arasında, karikatürün Türkçe öğretiminde etkili olduğu (Sever, 2007), öykünün öğrencilerin çevre duyarlı̆̆ını artırdığg (Özdemir, 1998; Özdemir, 2007) yönünde bulgulara ulaşıldığı araştırmalar sayılabilir.

Bütün bunlar, bilim eğitiminin estetik süreçlerle zenginleştirilmesinin öğrencilerin zihinsel uyanış yaşamalarında oldukça etkili olduğunu göstermektedir. Ancak, Türkiye'de eğitim süreçlerinde sanatın değerlendirilmesine yönelik referans alınabilecek kuramsal ve uygulamalı çalışmaların yok denilebilecek düzeyde az olması, büyük bir açık oluşturmaktadır. $\mathrm{Bu}$ durum, kavramsal temelden yoksun ve sanatı araçsallaştırıcı uygulamaların öne çıkmasına zemin hazırlamaktadır.

Bu çalışmada, göstergebilimin ve sanat eğitimi kuramları 1şı̆̆ında, bilim ve sanat pratiği irdelenerek sanatın bilim eğitiminde oynayabileceği role açıklık getirilmeye çalışılmıştır. Sonuç olarak, bilim eğitiminde sanat ürünlerinin henüz yeterince açığa çıarılmayan potansiyelinin değerlendirilmesine yönelik uygulama modellerinin tasarlanması ve sanat uzmanlarıyla işbirliği içinde yaşama geçirilebilmesine dönük araştırmaların ne kadar gerekli olduğu açıkça ortadadır.

\section{KAYNAKLAR}

Akarsu, B. (1979). Felsefe Terimleri Sözlü̆̆̈̈ (2. Baskı). Ankara: TDK Yayınları.

Andrew, N., Corbo, C., Wong, D., Greenfeder, G., Raths, L., Fulop, Z., College, W., Island, S. (2010). Combining Art And Science In "Arts and Sciences" Education. College Teaching: 55 (3), 114-120.

Arnheim, R. (2009). Görsel Düşünme (2. Baskl). (Çev: Rahmi Öğdül).İstanbul: Metis Yayınları.

Carr, D. (2005). On the contribution of literature and the arts to the educational cultivation of moral virtue, feeling and emotion. Journal of Moral Educaiton (June, 15 ).[Online]: Retrieved on 20-December2006,atURL:http://web.ebscohost.com/ehost/detail?vid=6\&hid=118\&s id=b4930949-0b74-46d5-a0a7-8926d530deb7\%40sessionmgr101.

Erzen, J. (2006). Çevre Estetiği (1.Baskı). Ankara: ODTÜ Geliştirme Vakfı Yayınları.

Göktürk, A. (1989). Sözün Ötesi (1.Baskı). İstanbul: İnkılâp Kitabevi. 
Götze, K. (1966). Die Kunsterziehungsbewegung , H. Lorenzen (Ed.) Zeichnen und Formen (ss. 27-33). Bad Helbrunn.

Gurevitz, R. (2000). Affective approaches to environmental education: going beyond the imagined worlds of childhood?. Ethics, Place and Environment ( January, 16). [Online]: Retrieved on 3-December2006, at URL: http://web.ebscohost.com/ehost/pdf?vid=10\&hid= 15\&sid=f38dff6b-119e-4795-ae9c-06f7372318cf\%40sessionmgr2.

İpşiroğlu, N. (1996). Duyu Algılarının Eğitimi: Çağdaş Eğitimde Sanat (2. Baskl). İstanbul: Demet Yayıncilık.

Kavcar, C. (1994). Edebiyat ve Ĕgitim Ankara: Ankara Üniversitesi. Eğitim Bilimleri Fakültesi Yayınları, No:171.

Langer, S.K. (1965). Phlosophie auf neuem Wege. Franfurt/M.

Moran, B. (2006). Edebiyat Kuramları ve Eleştiri (15. Baskı). İstanbul: İletişim Yayınları.

Morin, E. (2003). Geleceğin Ĕ̆itimi İçin Gerekli Yedi Bilgi (1. Baskl). İstanbul: İstanbul Bilgi Üniversitesi Yayınları.

Özdemir, O. (1998). "Yazınsal Bir Tür Olarak Öykü’nün Çevre Duyarlığına Etkisi." Yayımlanmamış yüksek lisans tezi, Ankara. Üniversitesi Sosyal Bilimleri Enstitüsü, Ankara.

Özdemir, O. (2006). Yazınsal Bir Tür Olarak Öykü'nün Çevre Duyarlığına Etkisi ve Çevre Eğitimi Açısından Değerlendirilmesi. Ĕğitim Araştırmaları Dergisi. 23, 159-167.

Öztürk, M.O (2002). Sorma-Bilme Dürtüsü ve Girişimi Duygusu Nasil Yok Ediliyor? (1.Baskl). Ankara: TÜBA Yayınları.

Ponty, M. (2005) Algılanan Dünya (1.Baskl). (Çev: Ö. Ayün). İstanbul: Metis Yayınları.

Read, H. (1970). Erziehung durch Kunst.München-Zürih.

Sahasrabudhe, P. (2006). Design for learning through the arts. International Journal of Education through Art (June, 20). [Online]: Retrieved on 20-December-2006, at URL: http://web.ebscohost.com/ ehost/pdf?vid=15\&hid=116\&sid=23cb7967-8520-4d9d-b71770961b5be50a\%40sessionmgr102

Richards, I.A. (1924). Principles of Literary Criticism. Routledge.

San, İ. (1979). Yaratıcılık İki Düşünme Biçimi ve Çocuğun Yaratıcı Eğitimi. Ankara Üniversitesi Ĕgitim Fakültesi Dergisi, 14, 177-190.

San, İ. (2003). Sanat Eğitimi Kuramları (2.. Baskl). Ankara: Ütopya Yayınları.

Sever, S. (27-29 Nisan 2007). Türkçe Öğretiminde, Sanatsal Bir Uyaran Olarak Karikatürün Kullanılması. VI. Ulusal Sınıf Öğretmenliği Sempozyumunda sunulmuş bildiri, Eskişehir. 
Uygur, N. (1984). Insan Açısından Edebiyat (3. Baskl). İstanbul: Remzi Kitabevi.

Zimmermann, H.D. (2001) Yazınsal İletişim (1.Baskı). (Çev: F., Tepebaşıl1). Konya: Çizgi Kitabevi. 